Reprod. Nutr. Dévelop., 1983, 23 (3), 575-586.

\title{
Lipogenic capacity and relative contribution of the different tissues and organs to lipid synthesis in male rat
}

\author{
G. GANDEMER, G. PASCAL, G. DURAND
}

Station de Recherches de Nutrition, I.N.R.A., 78350 Jouy-en-Josas, France

Summary. The rates of ${ }^{3} \mathrm{H}$ from ${ }^{3} \mathrm{H}_{2} \mathrm{O}$ incorporation into total lipids and fatty acids were measured in vivo in the different organs and tissues of 7-week old male Wistar rats to compare the lipogenic capacity of those organs and tissues and to determine their relative contributions to body lipid synthesis.

Our results were the following; (1) liver was the major site of the synthesis of total lipids and fatty acids (37 and $42 \%$, respectively, of body synthesis) ; (2) white adipose tissues synthesized about $24 \%$ of the total lipids; mesenteric adipose tissue and liver had equivalent lipogenic capacities per unit of weight, mesenteric adipose tissue alone synthesizing $40 \%$ of the fatty acids produced in dissectable white adipose tissues ; (3) skin showed low lipid synthesis but played an appreciable role in that synthesis $(8 \%$ of the total) due to its large contribution to total body weight ; (4) other organs (excluding liver) showed low lipid synthesis; however, that of the small intestine was $1-2 \%$ of body synthesis : (5) the rest of the carcass (mainly musculature and skeleton) contributed $25 \%$ to body lipid synthesis.

The putative roles of the different tissues and organs in adipose tissue development have been discussed.

\section{Introduction.}

Although in vivo lipid synthesis has been widely studied, the contribution of tissues and organs to this synthesis is not well known. This gap in our knowledge is related to methodological problems. It has been shown recently that different carbon precursors, such as glucose and acetate which have been widely employed in the past 10 years (Favarger, 1965; De Freitas and Depocas, 1965 ; Patkins and Masoro, 1964 ; Loten, Rabinovitch and Jeanrenaud, 1974), cannot be used to measure the total rate of fatty acid synthesis in all tissues, especially in liver; their use leads to an incorrect estimate of the relative contribution of different tissues to body fatty acid synthesis (Hems, Rath and Verrinder, 1975 ; Baker, Learn and Bruckdorfer, 1978). This is because tissue uptake of the different substrates and dilution of the precursor pools derived from various labelled substrates vary. The above studies showed the need of using such a precursor as tritiated water (Jungas, 1968 ; Lowenstein, 1971) to obtain an estimate of the rate of lipid synthesis, independent of the source of the carbon atoms incorporated. A number of authors have had recourse to ${ }^{3} \mathrm{H}_{2} \mathrm{O}$ when reconsidering the respective roles of different tissues in rodent lipid synthesis. 
Liver and white adipose tissues have been thoroughly studied in both mouse (Yen et al., 1976 ; Le Marchand-Brustel and Jeanrenaud, 1978 ; Cawthorne and Cornish, 1979 ; Cornish and Cawthorne, 1978 ; Rath and Thenen, 1980 ; Hollands and Cawthorne, 1981 ; Romsos and Leveille, 1974) and rat (Stansbie et al., 1976 ; Lakshmanan, Berdanier and Veech, 1977 ; Godbole and York, 1978 ; Kannan et al., 1980), the authors attributing 5 to $50 \%$ of the fatty acid synthesis to liver. Widely varying results have been obtained on various factors influencing lipid synthesis, such as nutrition (Baker, Learn and Bruckdorfer, 1978; Cawthorne and Cornish, 1979 ; Cornish and Cawthorne, 1978 ; Romsos and Leveille, 1974), genetics (Yen et al., 1976 ; Le Marchand-Brustel and Jeanrenaud, 1978; Cawthorne and Cornish, 1979 ; Rath and Thenen, 1980 ; Lakshmanan, Berdanier and Veech, 1977) and physiology (Le Marchand-Brustel and Jeanrenaud, 1978 ; Cornish and Cawthorne, 1978; Rath and Thenen, 1980), but all data indicate that the rest of the carcass is the main site of lipid synthesis. Of the many tissues in the carcass, only white adipose tissues have been thoroughly studied (Hems, Rath and Verrinder, 1975 ; Cornish and Cawthorne, 1978 ; Rath and Thenen, 1980 ; Hollands and Cawthorne, 1981 ; Stansbie et al., 1976 ; Godbole and York, 1978). Except in obese animals in which hypertrophied adipose tissues play a large role in lipid synthesis, all results show that this synthesis is lower in white adipose tissues than in liver and that the presence of these tissues in the carcass cannot wholly explain the intense lipogenic activity in extrahepatic tissues (Cawthorne and Cornish, 1979; Rath and Thenen, 1980; Hollands and Cawthorne, 1981 ; Kannan et al., 1980).

When the present work was started, there were no bibliographical data on the respective roles of extrahepatic tissues in lipid synthesis. A recent study of the relative contribution of many tissues and organs to lipid synthesis suggests that muscle may be the main site of that synthesis in mice (Hollands and Cawthorne, 1981). Moreover, intestines, skin and head seem to have as large a role in fatty acid synthesis as liver (Hollands and Cawthorne, 1981). Rath and Thenen (1980) showed that genetic factors induce wide variations in the estimate of the contribution of the main tissues to lipid synthesis. Therefore, it seems difficult to transpose the results obtained in one strain of mice to another strain, and even more difficult to transpose these results from one animal species, such as mouse, to another such as rat.

In the present study of the development of white adipose tissues, we have estimated the contribution of many organs and tissues to lipid synthesis to be able to determine its main sites in male rat. We used ${ }^{3} \mathrm{H}_{2} \mathrm{O}$ to measure the rate at which total lipids and fatty acids were synthesized. Some of the methodology was clarified before the experiment began. The putative role of each tissue in the storage of fatty acids in adipose tissue has been discussed.

\section{Material and methods}

Animals. - We used male Wistar CF rats 7 weeks old and weighing an average of $228 \mathrm{~g}$. Our reasons for choosing this particular developmental stage were : (1) the rate at which ${ }^{3} \mathrm{H}$ is incorporated into lipids throughout the rodent 
organism is maximal between 5 and 10 weeks of age (Le Marchand-Brustel and Jeanrenaud, 1978 ; Rath and Thenen, 1980) and (2) the principal tissues and organs (White adipose tissues, skin, carcass, liver) are large enough so that the specific radioactivity of their total lipids and fatty acids can measured individually.

From weaning at 21 days, the rats were fed a semi-purified diet containing $18 \%$ of protein and $0.3 \%$ of lipid. The diet composition and the daily food intake of the animals have been published previously (Gandemer, Pascal and Durand, 1979). This low-fat diet provides optimal conditions for studying de novo lipid synthesis (Pascal et al., 1977 ; Carroza et al., 1979).

The rats were reared in a room with controlled temperature $\left(22^{\circ} \mathrm{C}\right)$ and a light/dark cycle of $12 \mathrm{~h}$ of light and $12 \mathrm{~h}$ of darkness. The dark period extended from 3 a.m. to 3 p.m. The rats were killed between 9 and 10 a.m., i.e. 6 or $7 \mathrm{~h}$ after the beginning of the meal, so that lipid synthesis was maximal in tissues and organs (Hems, Rath and Verrinder, 1975 ; Cornish and Cawthorne, 1978).

In vivo ${ }^{3} \mathrm{H}$ incorporation into total lipids and fatty acids. - The incorporation of tritiated water ${ }^{3} \mathrm{H}$ into total lipids and fatty acids of tissues and organs was obtained as follows. Each animal was given a single intraperitoneal dose of ${ }^{3} \mathrm{H}_{2} \mathrm{O}$ $(2.5 \mathrm{mCi}$ in $0.5 \mathrm{ml}$ of $0.9 \% \mathrm{NaCl}$ solution) and then immediately returned to its cage ; $10 \mathrm{~min}$ later the rat was killed by decapitation. We chose $10 \mathrm{~min}$ as the interval between the time tracer injection was given and the time the animals were killed because preliminary methodological studies (Gandemer, Pascal and Durand, 1980) showed that 10 min after the tracer was injected (1) the ${ }^{3} \mathrm{H}_{2} \mathrm{O}$ was uniformly distributed throughout the organism, as attested by linear ${ }^{3} \mathrm{H}$ incorporation into the total lipids and fatty acids of the tissues and organs studied, and (2) the specific radioactivity of plasma fatty acids was still very low, indicating negligible intercellular exchange.

The blood was collected in a heparinized tube using a saline solution with $10 \%$ of heparin. After centrifugation, the plasma was stored at $-80^{\circ} \mathrm{C}$. The animal was skinned and dissected rapidly. The liver, heart, kidneys, lungs, pancreas, spleen, thymus, stomach, small intestine, large intestine, brain and testes were dissected out and weighed. The white adipose tissues were divided into 6 groups according to anatomical location, 3 of inner tissues (mesenteric, epididymal and perirenal) and 3 of outer tissues (dorsal subcutaneous, inguinal and " other adipose tissues "). "Other adipose tissues " included all the covering fat left after inguinal and dorsal subcutaneous tissues had been removed. The rest of the carcass was composed mostly of muscles and skeleton.

The adipose tissues, organs, skin and rest of the carcass were immediately immersed in liquid nitrogen as soon as they were dissected out.

Extraction of total lipids and fatty acids. - The skin and rest of the carcass were ground under a stream of liquid nitrogen. All tissues and organs, except white adipose tissues, were lyophilized to eliminate most of the tritiated water. Total lipids were extracted using the method of Folch (Folch, Lee and SloaneStandley, 1957). Weight and lipid content were high enough to permit individual 
extraction of total lipids in liver, skin, white adipose tissues and the rest of the carcass. The total lipids of organs other than liver were extracted from pools of an equal amount of dry matter from the homologous organs of each rat.

After a known quantity of the total lipids had been saponified with potassium hydroxide in alcoholic solution $(10 \mathrm{~g} / 1)$, the non-saponifiable was extracted with hexane and discarded. Fatty acids were extracted by hexane after the medium was acidified with hydrochloric acid.

The amounts of tissue total lipids and fatty acids were determined by weighing.

Measurement of sample radioactivity. - One hundred to 500-mg samples of total lipids or fatty acids were dissolved in hexane and thoroughly rinsed in distilled water to avoid any pollution of the samples by residual water. After solvent evaporation, the lipids were re-dissolved in $4 \mathrm{ml}$ of hexane and transferred to counting vials. The specific ${ }^{3} \mathrm{H}$ radioactivity of the plasma was determined by a sample of $25 \mu$ l of water, transferred directly to the counting vials.

The radioactivity of each sample was measured in a Beckman LS 9000 liquid scintillation counter. The scintillating liquid was Unisolve I Koch Light. The yield of each count was corrected by the channel ratio method.

Calculation. - The rates of total lipid and fatty acid synthesis were calculated using the following ratio :

$$
\frac{{ }^{3} \mathrm{H} \text { incorporated into lipids (in } \mathrm{dpm} / 10 \mathrm{~min} / \mathrm{g} \text { of tissue or whole tissue) }}{\text { specific radioactivity of }{ }^{3} \mathrm{H} \text { in plasma water (in } \mathrm{dpm} / \mu \mathrm{g} \text { of }{ }^{3} \mathrm{H} \text { at } 10 \mathrm{~min} \text { ) }}
$$

The results were expressed either in $\mu \mathrm{g}$ incorporated $/ 10 \mathrm{~min} / \mathrm{g}$ of fresh tissue or in $\mu \mathrm{g}$ of ${ }^{3} \mathrm{H}$ incorporated $/ 10 \mathrm{~min} /$ whole tissue.

The rates of total lipid and fatty acid synthesis in different tissues were compared using one $\mathrm{g}$ of fresh tissue as a basis ( $\mu \mathrm{g}$ of ${ }^{3} \mathrm{H} / 10 \mathrm{~min} / \mathrm{g}$ of tissue).

The rate of body total lipid or fatty acid synthesis was calculated by adding the rates measured in each tissue expressed in $\mu \mathrm{g}$ of ${ }^{3} \mathrm{H} / 10 \mathrm{~min} /$ whole tissue. The relative contribution of each tissue to body synthesis of the two lipid fractions was expressed in the \% of the total.

\section{Results}

All results are shown on table 1 .

Intensity of lipid synthesis in tissues and organs (in $\mu \mathrm{g}$ of ${ }^{3} \mathrm{H}$ incorporated into total lipids or fatty acids $/ 10 \mathrm{~min} / \mathrm{g}$ of tissue). - In our experimental conditions, lipid synthesis was higher in liver than in any other tissue or organ.

Lipid synthesis was low in organs other than liver. Its rate in small and large intestine, kidneys, lungs and thymus was 10 times lower than in liver, and in heart, stomach, spleen, brain and testes it was very low.

The intensity of lipid synthesis in dissectable white adipose tissues was two times lower than in liver. This value covered a very wide disparity in adipose tis- 
sue lipogenic activity in relation to anatomical location. In fact, at equal weight, the rate at which ${ }^{3} \mathrm{H}$ was incorporated into total lipids and fatty acids of mesenteric adipose tissue equalled that of liver. Lipid synthesis was higher in inner (perirenal and epididymal) adipose tissues than in outer (subcutaneous, inguinal and " other ") adipose tissues.

At the 7-week developmental stage, lipogenic activity in skin was very low. The intensity of total lipid and fatty acid synthesis in the rest of the carcass was comparable to that measured in skin. total).

Relative contribution of tissues and organs to lipid synthesis $1 \%$ of the

Liver. - Liver was the main site of lipid synthesis since it produced $36.6 \%$ of the total lipids and $41.8 \%$ of the fatty acids in the body.

Organs. - Organs other than liver contributed little to lipid synthesis : $7 \%$ of the total lipids and $6 \%$ of the newly synthesized fatty acids of the organism. Their minor role was due to low lipogenic capacity and to their moderate ponderal size ( $9 \%$ of body weight).

All the other organs except small intestine showed a negligible contribution to fatty acid synthesis. The relative importance of pancreas (1.8 of the total) was largely overestimated owing to the presence of mesenteric adipose tissue in the samples.

Dissectable white adipose tissues. - White adipose tissues represented $7 \%$ of animal body weight. They contained $43 \%$ of the total lipids of the body and contributed to 24 and $27 \%$ of the total lipids and fatty acids synthesized, respectively. Therefore, about half of the fatty acid synthesis in extrahepatic tissues was due to adipose tissues. Because of its remarkable lipogenic capacity, mesenteric adipose tissue alone synthesized 10 and $38 \%$, respectively, of the newlyfound fatty acids in the organism and white adipose tissues, while it represented hardly $1 \%$ of the body weight. The other white adipose tissues each contributed 1 to $5 \%$ of total lipid and fatty acid synthesis.

Skin and rest of the carcass. - Although the lipogenic capacity of the skin and the rest of the carcass was low, they played a marked role in lipid synthesis due to their ponderal size. Skin represented $19 \%$ of the body weight and contained $25 \%$ of the total lipids of the organism at the developmental stage studied. Its contribution to lipid synthesis was between 7 and $8 \%$ of the total.

The rest of the carcass (musculature and skeleton) weighed $116 \mathrm{~g}$ or onehalf of the body weight. When all the organs, dissectable white adipose tissues and skin had been removed, the rest of the carcass still contributed to a large part of the total lipid synthesis, and its low lipid content $(54 \mathrm{mg} / \mathrm{g})$ attested that the white adipose tissues had been dissected out well.

To summarize, liver was the main site of lipid synthesis in 7-week old male Wistar rat fed a carbohydrate-rich diet. About $58 \%$ of the newly formed fatty 


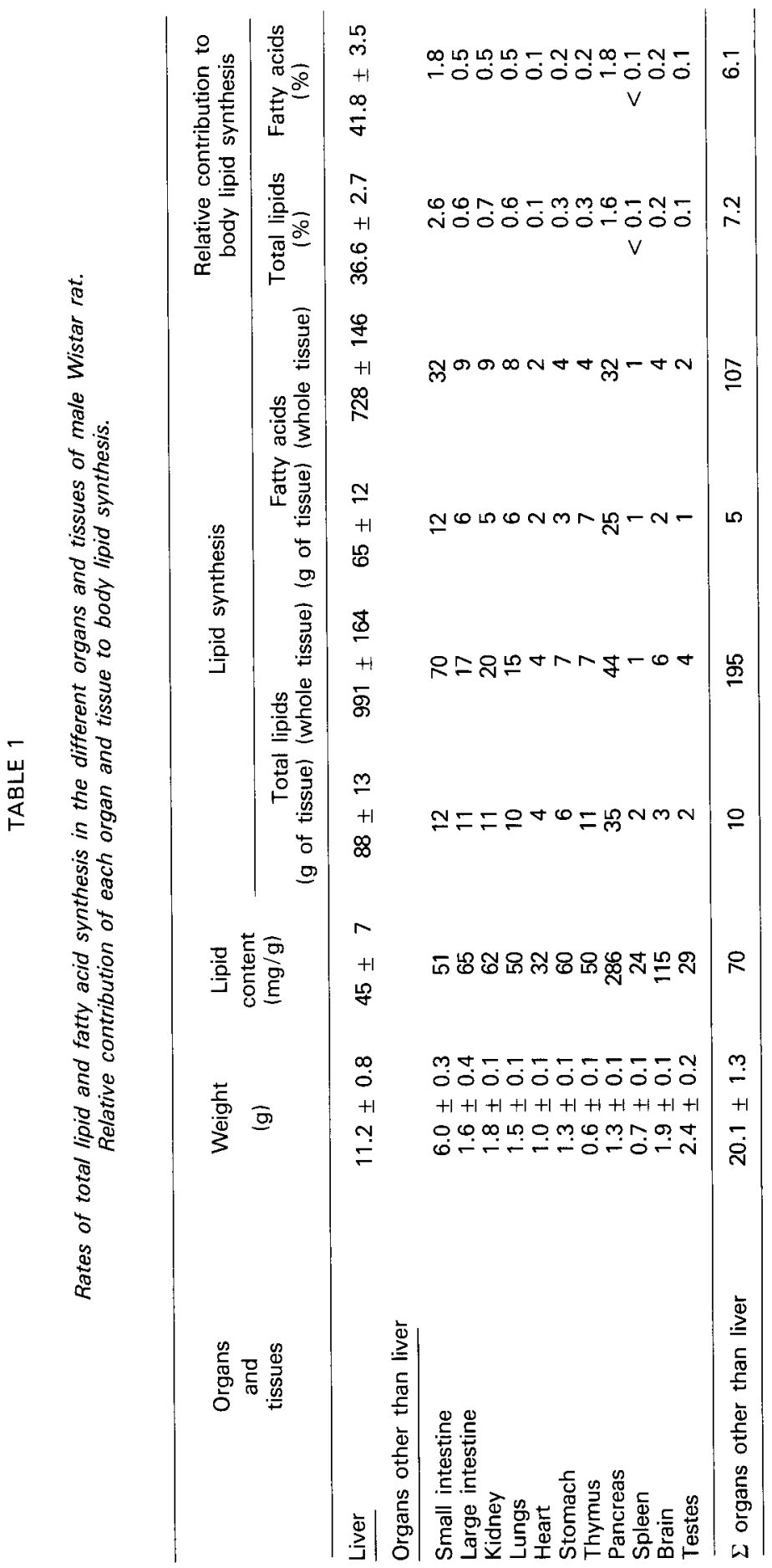




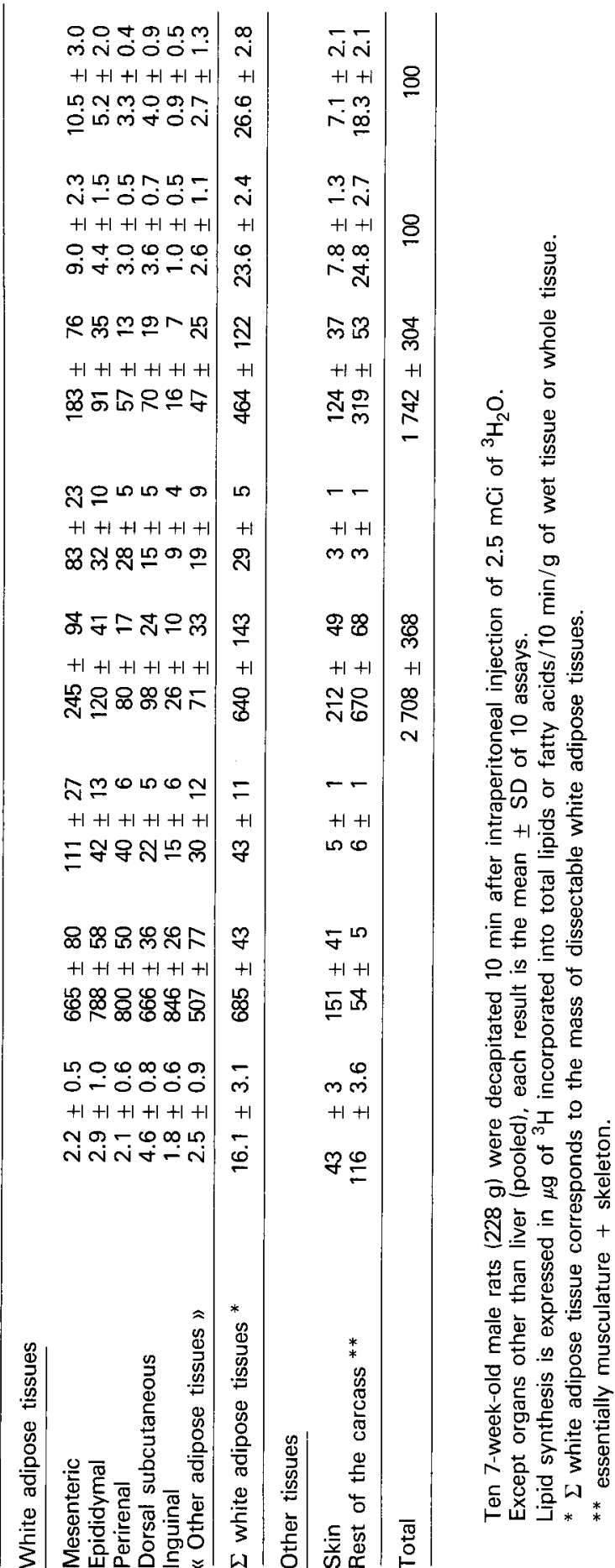


acids in the organism were synthesized in the extrahepatic tissues as follows : $1 / 2$ in white adipose tissues, $1 / 3$ in musculature and skeleton, $1 / 10$ in skin and $1 / 10$ in organs other than liver.

\section{Discussion.}

Hepatic lipid synthesis. - The liver was the site of intense lipid synthesis in 7-week old male Wistar rat fed a carbohydrate-rich diet ad libitum. Except for mesenteric adipose tissue, the intensity of lipid synthesis (per g of tissue) was at least two times higher in liver than in other tissues or organs. We have estimated that liver synthesized $42 \%$ of the total fatty acids, making it the major site of fatty acid synthesis in rat. Other studies have rarely attributed to the liver such an important role in lipid synthesis, although this estimate has varied (Yen et al., 1976 ; Le Marchand-Brustel and Jeanrenaud, 1978 ; Rath and Thenen, 1980 ; Romsos and Leveille, 1974). Hepatic lipid synthesis is mainly a result of such factors as nutrition (Baker, Learn and Bruckdorfer, 1978; Cawthorne and Cornish, 1979 ; Cornish and Cawthorne, 1978; Romsos and Leveille, 1974; Kannan et al., 1980) and genetics (Yen et al., 1976 ; Rath and Thenen, 1980 ; Lakshmanan, Berdanier and Veech, 1977). Dietary lipid content (Cawthorne and Cornish, 1979), type of carbohydrate supply (glucose/fructose) (Romsos and Leveille, 1974) and rhythm of food intake (Baker, Learn and Bruckdorfer, 1978) ; Cornish and Cawthorne, 1978; Kannan et al., 1980) all modify in a large measure the intensity of fatty acid synthesis in liver. By using a carbohydrate-rich diet $175 \%$ of carbohydrate, $1 / 3$ of which was saccharose) containing little fat, we created favourable conditions for hepatic lipid synthesis. In fact, a very low level of lipid and a high level of fructose in the diet considerably increase lipid synthesis in rat liver (Cawthorne and Cornish, 1979 ; Romsos and Leveille, 1974).

Lipid synthesis in organs other than liver. - All organs except liver showed low lipid synthesis. The contribution of these organs to fatty acid synthesis did not exceed $6 \%$. Among those studied, only small intestine played an appreciable role in lipid synthesis. Although there are no comparative data in the literature on organ contribution to lipid synthesis in rat, a study in mouse has shown that kidneys, lungs, brain and heart synthesize few fatty acids (Hollands and Cawthorne, 1981). Our estimate of the contribution of intestines to lipid synthesis in rat is close to that found in mouse by Rath and Thenen (1980) but much lower than reported by Hollands and Cawthorne (1981) who attributed to intestines a role equivalent to that of liver. In the latter work, mesenteric white adipose tissue was not separated from the intestines. However, this adipose tissue has remarkable lipogenic capacity (our results, Patkins and Masoro, 1964; Hems, Rath and Verrinder, 1975), and its presence in intestinal samples leads to an overestimate of intestinal contribution to fatty acid synthesis. In our study, mesenteric adipose tissue was not completely removed from diffuse pancreas either, which would explain the excessively high lipogenic value we obtained for the pancreas. 
Lipid synthesis in white adipose tissues. - Dissectable white adipose tissues represented $7 \%$ of the body weight and $43 \%$ of the total lipids of the rat organism.

The rates of total lipid and fatty acid synthesis (per g of tissue) were, on the average, much lower than the rate measured in the liver, confirming previous results (Hems, Rath and Verrinder, 1975; Cornish and Cawthorne, 1978; Rath and Thenen, 1980 ; Stansbie et al., 1976). The relative contribution of dissectable white adipose tissues to body lipid synthesis was $27 \%$ or almost half of that of the rate of fatty acid synthesis in extrahepatic tissues. However, white adipose tissues were very heterogeneous, their lipid content and metabolic activity varying with anatomical location. Thus, at equal weight, mesenteric adipose tissue and liver synthesized equivalent amounts of fatty acids which were 2 to 3 times higher than those synthesized by other inner (epididymal, perirenal) adipose tissues. Mesenteric adipose tissue alone synthesized $40 \%$ of the newly formed fatty acids in adipose tissues. Synthesis was more intense in inner than outer (dorsal subcutaneous and inguinal) adipose tissues. Favarger and Gerlach (1955) attributed these differences in lipid synthesis to the mode of tracer administration (intravenous, intraperitoneal or subcutaneous). They observed that the closer the adipose tissue was to the site of tracer injection, the higher was the amount of tracer incorporated into the fatty acids. From our results, we believe that differences in lipid synthesis in adipose tissues from various anatomical sites are really due to differences in lipogenic capacity. Our conclusion is based on three facts : (1) by measuring the rate of fatty acid synthesis with tritiated water, we obtained homogeneous distribution of the tracer throughout the organism within a few minutes. We thus avoided the slow diffusion causing heterogeneous tracer distribution, as in the study of Favarger and Gerlach (1955) using ${ }^{14} \mathrm{C}$ precursor; (2) results comparable to ours were obtained by Godbole and York (1978) using intravenous injection of ${ }^{3} \mathrm{H}_{2} \mathrm{O}$ and by Patkins and Masoro (1964) using per os administration of ${ }^{14} \mathrm{C}$-glucose ; (3) in vitro observations (Gandemer, Pascal and Durand, 1979 ; Benjamin et al., 1971) have led to the same conclusion.

These results on the heterogeneity of white adipose tissues show that it is risky to try to estimate the contribution of body adipose mass to fatty acid synthesis by measuring the rate of ${ }^{3} \mathrm{H}$ incorporation into the fatty acids of only one or two adipose tissues.

Lipid synthesis in skin. - The skin of 7-week old Wistar rats synthesized $7 \%$ of the total fatty acids. We found no comparative data in the literature on rat; on the contrary, in mouse, skin plays a large role in fatty acid synthesis since it synthesizes 15 to $30 \%$ of the body lipids (Rath and Thenen, 1980 ; Hollands and Cawthorne, 1981).

Lipid synthesis in musculature and skeleton. - Lipid synthesis was low in the rest of the carcass, mainly composed of musculature and skeleton. But, considering its weight, the rest of the carcass played a considerable role in lipid synthesis, contributing about $18 \%$ of the body fatty acids. Since bones synthe- 
size little lipid (Favarger, 1965), almost all fatty acid synthesis in the rest of the carcass appeared to be localized in musculature. However, data on the exact anatomical site of lipogenic activity in musculature are contradictory. According to some authors, this activity would be due to intermuscular adipose tissue (Kannan, Palmquist and Baker, 1976) or to muscle fibers themselves (Hollands and Cawthorne, 1981). The present study does not answer this question directly. However, the amount of total lipid in the rest of the carcass (musculature + skeleton) was low (54 $\mathrm{mg} / \mathrm{g}$ of fresh tissue), being about the same order as that of organs. Therefore, it is probable that intermuscular adipose tissue is very little developed in 7-week old Wistar rat and cannot account for the large contribution of the musculature to fatty acid synthesis. For this reason, we think it is more plausible to attribute lipid synthesis in musculature to the muscle fibers themselves.

In any case, musculature is not the main site of lipid synthesis in rat, contrary to recent results obtained in mouse (Rath and Thenen, 1980 ; Hollands and Cawthorne, 1981).

Some thoughts on the development of white adipose tissues. - In vivo measurement of the rate of total lipid synthesis in adipose tissues supplies information on the way these tissues develop. In fact, the rate of triglyceride glycerol synthesis can be estimated from the synthesis rates of total lipids and fatty acids in adipose tissues. This calculation is based on the following observation : we found only 1 to $2 \%$ of the total lipids in the non-saponifiable, thus confirming the results of Jungas (1968) and Stansbie et al. (1976); therefore, the difference between the rates of total lipid and fatty acid synthesis gives a good estimate of the rate of triglyceride glycerol synthesis in adipose tissues (Jungas, 1968). From data on table 1, we can calculate that the rate of ${ }^{3} \mathrm{H}$ incorporation into glycerol in the whole of the white adipose tissues was $176 \mu \mathrm{g}$ of ${ }^{3} \mathrm{H} / 10 \mathrm{~min}(640-464=176)$. According to Jungas (1968), the amounts of ${ }^{3} \mathrm{H}$ (in $\mu \mathrm{g}$ ) incorporated during the synthesis of $1 \mu$ mole of palmitic acid and $1 \mu$ mole of glycerol are 13.3 and 3.3, respectively.

Consequently, dissectable white adipose tissues synthesized $53 \mu$ moles of glycerol (176:3.3) vs about $35 \mu$ moles of fatty acids (464:13.3) at the developmental state and time of the light/dark cycle used in the present study. Fiftythree $\mu$ moles of glycerol might esterify $159 \mu$ moles of fatty acids $(53 \times 3)$, of which $35 \mu$ moles (only $22 \%$ ) were synthesized in situ. Thus, most of the fatty acids stored in adipose tissues must have been taken up in blood. We may conclude from this that fatty acid uptake from blood plays a dominant role in the development of white adipose tissues in Wistar rat fed a low-fat diet. This conclusion agrees with that of Borensztajn and Getz (1972). On the contrary, it questions results obtained by many authors who conclude that the transport and uptake of plasma fatty acids are secondary processes in adipose tissue development (Favarger, 1965 ; Patkins and Masoro, 1964 ; Haft, 1973).

Due to high adipose tissue uptake of plasma fatty acids, only organs with high lipogenic capacity can contribute to the development of these tissues. Of the many dissected tissues and organs, only liver appears to be able to export 
enough fatty acids to affect the development of the adipose tissues. The rest of the carcass, which contributes largely $(18 \%)$ to fatty acid synthesis, may play a role in triglyceride storage; however, musculature, the main component of this body fraction, is a privileged site for fatty acid oxidation. Thus, it does not seem very likely that the carcass could export appreciable amounts of fatty acids into the blood.

Reçu en février 1982.

Accepté en janvier 1983.

Résumé. Capacité lipogénique et contribution des différents tissus et organes à la synthèse des lipides chez le Rat mâle.

L'incorporation du ${ }^{3} \mathrm{H}$ de l'eau tritiée dans les lipides totaux et les acides gras a été mesurée in vivo dans la plupart des tissus et organes du rat mâle Wistar âgé de 7 semaines pour comparer la capacité lipogénique de ces tissus et organes et déterminer leur contribution relative à la synthèse des lipides corporels.

Les résultats conduisent aux conclusions suivantes :

1. Le foie est l'agent principal de la synthèse des lipides totaux et des acides gras (37 et $42 \%$ respectivement de la synthèse corporelle totale).

2. Les tissus adipeux blancs synthétisent environ $24 \%$ des lipides totaux. Par unité de poids, le tissu adipeux mésentérique et le foie présentent une capacité lipogénique équivalente ; le tissu adipeux mésentérique synthétise à lui seul $40 \%$ des acides gras élaborés par l'ensemble des tissus adipeux blancs dissécables.

3. La peau présente une activité lipogénique assez faible ; mais en raison de l'importante part du poids vif qu'elle représente, elle intervient de façon appréciable $(8 \%)$ dans la lipogénèse de l'organisme entier.

4. En dehors du foie, les organes ne jouent individuellement qu'un rôle minime dans la lipogenèse, si ce n'est l'intestin grêle dont la contribution à la lipogenèse globale se situe entre 1 et $2 \%$.

5. Le reste de la carcasse, constitué essentiellement de la musculature et du squelette, contribue pour $25 \%$ à la synthèse globale de lipides.

Le rôle possible des différents tissus et organes dans le développement des tissus adipeux est discuté.

\section{References}

BAKER N., LEARN D. B., BRUCKDORFER R. K., 1978. Reevaluation of lipogenesis from dietary glucose carbon in liver and carcass of mice. J. Lipid Res., 19, 879-893.

BENJAMIN W., GELHORN A., WAGNER M., KUNDEL H., 1961. Effect of age on lipid composition and metabolism in the adipose tissues of the rat. Am. J. Physiol., 201, 540-546.

BORENSZTAJN J., GETZ G. S., 1972. The contribution of lipogenesis in situ to the accumulation of fat by rat adipose tissue. Biochim. biophys. Acta, 280, 86-93.

CARROZA G., LIVREA G., CAPONETTI R., MANASSERI L., 1979. Response of rat hepatic fatty acid synthesis and activities of related enzymes to changes in levels of dietary fat. J. Nutr., 109, 162-170.

CAWTHORNE M. A., CORNISH S., 1979. Lipogenesis in vivo in lean and genetically obese (ob/ob) mice fed on diets with high fat content. Int. J. Obesity, 3, 83-90.

CORNISH S., CAWTHORNE M. A., 1978. Fatty acid synthesis in mice during the $24 \mathrm{hr}$ cycle and during meal feeding. Horm. Metab. Res., 10, 286-290.

DE FREITAS A. S., DEPOCAS F., 1965. Fatty acid and glyceride glycerol synthesis from glucose during high rats of glucose uptake in the intact rat. Can. J. Biochem., 43, 437-450. 
FAVARGER P., 1965. Relative importance of different tissues in the synthesis of fatty acids. In: RENOLD A. E., CAHILL G. F. Handbook of physiology: Sect. 5, Adipose tissue. Chap. 4, 19-24. Washington D. C., Am. physiol. Soc.

FAVARGER P., GERLACH J., 1955. Recherches sur la synthèse des graisses à partir d'acétate ou de glucose. I. Vitesse d'incorporation de l'acétate dans les acides gras de la Souris amaigrie. Helv. physiol. Acta, 13, 91-95.

FOLCH J., LEE M., SLOANE-STANDLEY G. H., 1957. A simple method for the isolation and purification of total lipids from animal tissue. J. biol. Chem., 226, 487-509.

GANDEMER G., PASCAL G., DURAND G., 1979. Developmental changes in lipogenic enzyme activities in liver and adipose tissue of postweaning rats. Effect of sex and castration. Ann. Biol. anim. Bioch. Biophys., 19, 573-581.

GANDEMER G., PASCAL G., DURAND G., 1980. Etude de la lipogenèse de novo : cinétique $\mathrm{d}^{\prime}$ incorporation, in vivo, du ${ }^{3} \mathrm{H}$ de l'eau tritie dans les acides gras et les lipides totaux du foie, du plasma, du tissu adipeux et de la carcasse du rat mâle. C.R. Acad. Sci. Paris, 290, sér. D, 1479-1482.

GODBOLE V., YORK D. A., 1978. Lipogenesis in situ in the genetically obese Zucker fatty rat $(\mathrm{fa} / \mathrm{fa})$ : role of hyperphagia and hyperinsulinemia. Diabetologia, 14, 191-197.

HAFT D. E., 1973. Role of plasma triglyceride turnover in deposition of newly synthesized fatty acids in adipose tissue. Horm. Metab. Res., 5, 449-453.

HEMS A. D., RATH E. A., VERRINDER T. R., 1975. Fatty acid synthesis in liver and adipose tissues of normal and genetically obese (ob/ob) mice during the 24-hour cycle. Biochem. J., 150, 167-173.

HOLLANDS M. A., CAWTHORNE M. A., 1981. Important sites of lipogenesis in the mouse other than liver and white adipose tissue. Biochem. \&., 196, 645-647.

JUNGAS R. L., 1968. Fatty acid synthesis in adipose tissue incubated in tritiated water. Biochemistry, 7, 3708-3717.

KANNAN R., LEARN D. B., BAKER N., ELOVSON J., 1980. Fatty acid synthesis in vivo and hepatic contribution to whole body lipogenic rates in obese zucker rats. Lipids, 15, 993-998.

KANNAN R. L., PALMQUIST D., BAKER N., 1976. Contribution of intermuscular fat to lipogenesis from dietary glucose carbon in mice. Biochim. biophys. Acta, 431, 225-232.

LAKSHMANAN M. R., BERDANIER C. D., VEECH R. L., 1977. Comparative studies of lipogenesis and cholesterogenesis in lipemic BHE rats and normal Wistar rats. Arch. Biochem. Biophys., 183, 355-360.

LE MARCHAND-BRUSTEL Y., JEANRENAUD B., 1978. Pre- and postweaning studies on the development of obesity in mdb mice. Am. J. Physiol., 234, E 568-E 574.

LOTEN E. G., RABINOVITCH A., JEANRENAUD B., 1974. In vivo studies of lipogenesis in obese hyperglycemic $(\mathrm{ob} / \mathrm{ob})$ mice : possible role of hyperinsulinemia. Diabetologia, 10, 4552.

LOWENSTEIN J. M., 1971. Effect of (-) hydroxycitrate on fatty acid synthesis by rat liver in vivo. J. biol. Chem., 246, 629-632.

PASCAL G., DURAND G., MACAIRE J. P., PENOT E., 1977. Evolution de l'activité de l'acétylCoA-carboxylase et de la lipoprotéine-lipase dans le foie et les tissus adipeux du rat mâle au cours du développement après sevrage. Ann. Biol. anim. Bioch. Biophys., 17, 827-849.

PATKINS J. K., MASORO E. J., 1964. Fatty acid synthesis in normal and cold-acclimated rats. Can. J. Biochem., 42, 101-107.

RATH E. A., THENEN S., 1980. Influence of age and genetic background on in vivo fatty acid synthesis in obese (ob/ob) mice. Biochim. biophys. Acta, 618, 18-27.

ROMSOS D. R., LEVEILLE G. A., 1974. Effect of dietary fructose on in vitro and in vivo fatty acid synthesis in the rat. Biochim. biophys. Acta, 360, 1-11.

STANSBIE D., BROWNSEY R. W., CRETTAZ M., DENTON R. M., 1976. Acute effects in vivo of anti-insulin serum on rates of fatty acid synthesis and activities of acetyl-coenzyme $A$ carboxylase and pyruvate dehydrogenase in liver and epididymal adipose tissue of fed rats. Biochem. I., 160, 413-416.

YEN T. T., ALLAN J. A., PAO-LO YU, ACTON M. A., PEARSON D. V., 1976. Triacylglycerol contents and in vivo lipogenesis of ob/ob, db/db and Avy/a mice. Biochim. biophys. Acta, 441, 213-220. 